\title{
Portfolio Risk Management Implications of Mutual Fund Investment Objective Classifications
}

\author{
Larry J. Prather \\ Department of Accounting \& Finance, Southeastern Oklahoma State University, Durant, USA \\ Email: lprather@se.edu
}

Received July $15^{\text {th }}, 2012$; revised August 22 ${ }^{\text {nd }}, 2012$; accepted August $30^{\text {th }}, 2012$

\begin{abstract}
I examine portfolio risk management implications of using hypothetical investment returns from a sample of mutual funds in a variety of investment objective classifications to select mutual funds. While early research supported this practice by showing that risk is homogeneous within investment objective groups and heterogeneous between groups, more recent research suggests that earlier findings are no longer true. Research also suggests that load and no-load funds may exhibit risk differences. I examine whether risk is homogeneous within investment classification and heterogeneous between classes after controlling for potential load effects. Results reveal that significant risk differences exist even after controlling for the load structure of the fund and that those risk differences can have significant implications for portfolio risk management.
\end{abstract}

Keywords: Mutual Funds; Investment Objectives; Mutual Fund Risk

\section{Introduction}

Finance theory suggests that risk and return are essential elements in selecting investments. Utility theory further suggests that understanding the risk and return of mutual funds is crucial to investors in order to maximize the investors' satisfaction (utility) with an investment.

Many mutual funds exist from which investors can choose in building their investment portfolio. Practitioners often assist with the selection process by ascertaining the investors risk tolerance and then providing hypothetical investment results of suitable mutual funds that illustrate the return of various investment options. Investors then use the hypothetical investment results to compare the returns that would have been achieved if an investment had been made in the selected funds. This approach provides the investors with a benchmark that they can use to assess the relative performance of their investments.

The above approach is suitable if the investment objectives properly convey risk as suggested by Sharpe (1966) and Klemkosky (1976). However, for investment objectives to properly convey risk, the objectives must be systematically related to a quantitative measure of risk such as beta or volatility. Also, risk must be homogeneous within investment objective and heterogeneous between classes. However, if the risks of funds within an investment objective class differ, comparing returns alone is insufficient to make utility maximizing investment decisions. Unfortunately, Najand and Prather (1999) reported that risk is heterogeneous within investment objective groups. Therefore, the practice of comparing returns does not appear optimal.

I extend the work of Najand and Prather (1999) to incorporate the findings of Chordia (1996) that no-load fund portfolio managers hold more cash to meet a higher level of uncertain redemptions. This implies that systemic differences in risk between load and no-load funds may occur. Malhotra and McLeod (1997) also reported that load and no-load funds may have risk differences because they found that no-load funds have a higher cash ratio. Chordia's (1996) work suggests that one factor that may drive the reported risk heterogeneity is that risks differ systematically between load and no-load funds. Chordia (1996) characterized no-load fund investors as less loyal to a fund that performs poorly. Therefore, no-load fund managers must be sensitive to performance. This is consistent with the findings of Brown, Harlow and Starks (1996) that the "tournament" effect that is strongest with no-load funds. If more frequent switching by no-load fund investors causes no-load fund portfolio managers to respond by holding more cash to meet uncertain redemptions, that singular action could cause no-load funds to have lower risk than load funds in the same investment objective if investment constraints result in similar portfolios of risky assets.

The remainder of the paper is organized as follows. The next section, Data Sources and Methodology presents the data sources that I use and the methods that I employ to conduct statistical analysis. The Empirical Results section provides the results of empirical tests of risk homogeneity of mutual funds in five investment objectives classes. These results compare systematic risk using three difference indices and also compare total risk as well. My conclusions are presented in the Conclusion section.

\section{Data Sources and Methodology}

Thirteen years of monthly return data was obtained from CDA Investment Technology, Incorporated and screened using a process similar to that of Grinblatt and Titman (1989, 1992, 1993, and 1994) and Najand and Prather (1999). Table 1 presents the sample size by the CDA investment objective classification.

CDA's return data is also used for the risk-free proxy (90day T-bill return) while The Center for Research in Security Prices (CRSP) return data is used for the CRSP equally weighted 
Table 1.

Sample.

\begin{tabular}{lc}
\hline \multicolumn{1}{c}{ CDA Investment Objective } & Number of Funds \\
\hline Aggressive Growth (AG) & 43 \\
Growth (G) & 112 \\
Growth and Income (GI) & 66 \\
Balanced (B) & 36 \\
Bond and Preferred Stock (BP) & 66 \\
Total & 323 \\
\hline
\end{tabular}

Note: Column one presents the CDA investment objective classification and colu$\mathrm{mn}$ two presents the sample size for that investment objective.

(EW) and value weighted (VW) indices. Return data for the Morgan Stanley Capital International Perspective Index (MSCI) is also used as a benchmark for globally diversified investors. Because Brown and Brown (1987) and Lehmann and Modest (1987) reported that the selection of the index can have substantial impact on performance evaluation, using multiple indices when computing risk measures helps ensure that the results are robust with respect to the index.

\section{Computation of Returns}

Continuously compounded monthly net returns are computed by taking the natural $\log$ of the change in wealth over each of the 156-month holding periods as shown in Equation (1).

$$
R_{i, t}=\ln \left[\left(N A V_{i, t}+D V_{i}+C G_{i}\right)\right] / N A V_{i, t-1}
$$

where: $R_{i, t}$ is the return on fund $i$ during period $t, N A V_{i, t}$ is the net asset value of fund $i$ at time t, $D V_{i}$ is the dividend and interest paid on fund $i$ during the period, and $C G_{i}$ is the capital gain distribution paid on fund $i$ during the period. Index returns are computed similarly.

\section{Determination of Systematic Risk}

Systematic risk is determined by using ordinary least squares regression (OLS) and the Capital Asset Pricing Model (CAPM). The model used is:

$$
R_{m f}-R_{f, t}=\alpha+\beta\left(R_{m, t}-R_{f, t}\right)+\varepsilon_{t}
$$

where $R_{m f}$ is the return on the mutual fund, $R_{f}$ is the return on the risk-free asset (90-day T-bill), and $R_{m}$ is the return on the market proxy. $\beta$ measures the systematic risk for each mutual fund from the perspective of an investor that holds a portfolio identical to the selected market proxy. If the investment objecve classification conveys risk, the $\beta$ 's for funds within each investment objective classification should not differ signifiantly from one another for a given index, although it may differ for different indices.

\section{Empirical Results}

The mutual fund's prospectus details specific constraints about the investment composition of the fund and cannot be changed without shareholder's approval since it would alter the basic characteristics of the investment. Based, at least in part, on this information, funds are classified into an investment objective. If investment constraints are binding and the investment objectives are good surrogates for risk, risk should be homogeneous within an investment objective group and heterogeneous between groups. To examine the usefulness of in- vestment objectives as risk proxies, the risks that investors would experience had they invested in the funds are estimated.

Table 2 presents the results of estimating the systematic risk or beta $(\beta)$ for each fund over the 156-month period. Betas can vary with the selected index since $\beta=(\mathrm{Cov} \mathrm{Ri}, \mathrm{Rm}) / \mathrm{o}_{\mathrm{m}}{ }^{2}$ therefore, three indices were utilized to ascertain the impact of index selection on beta computation. The results suggest that the systematic risk of funds within each investment objective group varies widely, despite the selected market proxy. The large range in estimated systematic risk is consistent with the findings of Najand and Prather (1999) and suggests that risk may not be homogeneous within each investment objective classification. Therefore, I now test the hypothesis that risk is homogeneous within investment objective groups to find out if these differences are statistically significant or due solely to chance.

\section{Systematic Risk Homogeneity Tests}

To conduct statistical testing, $\beta$ s are computed using monthly data over rolling one-year periods for the thirteen-year period. This provides a distribution of $144 \beta$ s for each of the 323 funds for each of the five indexes. These $\beta$ s are then compared using One-way ANOVA to test the equality of $\beta$ s within each investment objective group to learn if the average $\beta$ for all funds within the investment objective group are equal. Formally, ANOVA will be utilized to test:

HO: $\beta_{i, 1, t}=\beta_{i, 2, t}=\beta_{i, 3, t}=\cdots=\beta_{i, \mathrm{n}, t}$

HA: not all $\beta_{i}$ are equal

where $\beta_{i, 1, t}$ represents the estimated systematic risk $(\beta)$ of fund 1 using index $i$ during period $t$. The null hypothesis is that the average systematic risk for each fund within the investment objective group is equal. My methodology follows Klemkosky (1976) and Najand and Prather (1999). The critical value of the F statistic $\left(F^{*}\right)$ is computed using Equation (3)

$$
F^{*}=\left[\operatorname{SSE}(R)-\operatorname{SSE}(F) / d f_{r}-d f_{f}\right] /\left[\operatorname{SSE}(F) / d f_{f}\right](3)
$$

where $\operatorname{SSE}(R)$ and $\operatorname{SSE}(F)$ are the explained sum of squares for the reduced and full models respectively, and $d f_{r}$ and $d f_{f}$ are the degrees of freedom for the reduced and full models respecttively.

Table 3 presents results of the one-way ANOVA $F$-test to determine if the risk differences reported in Table 2 are statistically significant or whether they can be attributed to chance. Interestingly, statistical testing rejects the null hypothesis that risk is homogeneous within investment objective classes for most investment objective index combinations. Four of five investment objectives exhibit heterogeneous risk with the

Table 2.

Range of Estimated Betas.

\begin{tabular}{ccccc}
\hline \multirow{2}{*}{$\begin{array}{c}\text { Investment } \\
\text { Objective }\end{array}$} & \multirow{2}{*}{ Number of Funds } & \multicolumn{3}{c}{ Index (maximum/minimum) } \\
\cline { 3 - 5 } & & CRSP EW & CRSP VW & MSCI \\
\hline AG & 43 & $1.46 / 0.70$ & $1.57 / 0.81$ & $1.14 / 0.63$ \\
(G) & 112 & $1.18 / 0.36$ & $1.29 / 0.47$ & $0.94 / 0.38$ \\
(GI) & 66 & $0.93 / 0.25$ & $1.06 / 0.25$ & $0.80 / 0.19$ \\
(B) & 36 & $0.88 / 0.30$ & $0.99 / 0.32$ & $0.73 / 0.25$ \\
(BP) & 66 & $0.67 / 0.00$ & $0.68 / 0.00$ & $0.52 / 0.00$ \\
\hline
\end{tabular}

Note: Column one provides the CDA investment objective and column two lists the number of funds comprising the sample. Columns three and four are the estimated systematic risk measures for domestic investors using the CRSP EW and CRSP VW indices as market proxies, respectively. Column five is the estimated systematic risk for globally diversified investors using the MSCI index as a market proxy. 
Table 3.

Homogeneity of Systematic Risk within CDA Investment Objective Classes.

\begin{tabular}{ccccc}
\hline \multirow{2}{*}{$\begin{array}{c}\text { Investment } \\
\text { Objective }\end{array}$} & \multirow{2}{*}{ Number of Funds } & \multicolumn{3}{c}{ Index (F value) } \\
\cline { 3 - 5 } & & CRSP EW & CRSP VW & MSCI \\
\hline AG & 43 & $3.135^{* *}$ & $2.135^{* *}$ & 0.506 \\
(G) & 112 & 1.094 & 0.995 & $0.94 / 0.38$ \\
(GI) & 66 & $7.286^{* *}$ & $9.962^{* *}$ & $2.538^{* *}$ \\
(B) & 36 & $4.752^{* *}$ & 0.999 & $1.471^{*}$ \\
(BP) & 66 & $1.937^{* *}$ & $2.58^{5 * *}$ & $2.047^{* *}$ \\
\hline
\end{tabular}

Note: This table presents results of the one-way ANOVA F-test to determine if risk differences observed in Table 2 are statistically significant or whether they can be attributed to chance. Column one provides the CDA investment objective and column two lists the number of funds comprising the sample. Columns three and four are the ANOVA F-statistics for the tests of the null hypotheses that the risk for domestic only investors is homogeneous within the investment objective group. Column five is the ANOVA F-statistic for the test of the null hypothesis that the risk for globally diversified investors (MSCI) is homogeneous within the investment objective group. ${ }^{* * *}$ Indicates significance at the 0.01 and 0.05 levels, respectively.

CRSP EW index and three of the five investment objectives exhibit heterogeneous risk with the CRSP VW and MSCI indexes. Moreover, two of the five investment objective classes exhibit heterogeneous risk with all three indexes and another two of the five investment objective classes exhibit heterogeneous risk with two of the three indexes.

\section{Differences in Systematic Risk between Load and No-Load Funds}

Chordia (1996) and Malhotra and McLeod (1997) reported that load funds hold less cash than no-load funds. Presumably, this is due to a more stable clientele and redemptions that are more predictable. The act of holding dissimilar amounts of cash could cause systemic differences in risk between load and no-load funds. If no-load funds hold more cash and fewer risky assets, they would be less risky ceteris paribus because the standard deviation of a portfolio $\left(\sigma_{\mathrm{p}}\right)$ is equal to the product of the weight in the risky asset $\left(\mathrm{w}_{\mathrm{r}}\right)$ and the standard deviation of the risky asset $\left(\sigma_{\mathrm{r}}\right)$ or $\sigma_{\mathrm{p}}=\mathrm{w}_{\mathrm{r}}\left(\sigma_{\mathrm{r}}\right)$. Therefore, as the proportion of cash increases $\left(\mathrm{w}_{\mathrm{c}}\right)$, the proportion of the total investment in the risky portfolio $\left(\mathrm{w}_{\mathrm{r}}\right)$ decreases and so does the standard deviation of the portfolio $\left(\sigma_{\mathrm{p}}\right)$. This would decrease the systematic risk $(\beta)$ as well since the beta of a portfolio $\left(\beta_{\mathrm{p}}\right)$ can be expressed as $\beta_{\mathrm{p}}=\rho\left(\sigma_{\mathrm{p}} / \sigma_{\mathrm{m}}\right)$, where $\rho$ is the correlation between the portfolio and the market and $\sigma_{\mathrm{p}}$ and $\sigma_{\mathrm{m}}$ are the portfolio and market variabilities, respectively. Alternatively, the beta of a portfolio is the weighted sum of the beta of each asset times the beta of the asset. Because the beta of cash is zero, a portfolio with higher cash holdings would have a smaller beta ceteris paribus.

Brown, Harlow, and Starks (1996) found that no-load fund managers with a poor performance record in the first half of the year alter risk in the second half of the year to improve performance suggesting that no-load funds investors may be more sensitive to performance. Chordia (1996) believes that is the case and that switching costs create differences in loyalty between load and no-load fund investors. He believes that this mitigates fund flows for load funds and therefore creates different effects for load and no-load portfolio managers. Therefore, the load structure may explain the documented heterogeneous within group risk.

To test the hypothesis that systematic risk is homogeneous between the load and no-load funds for each investment objec- tive, the sample was segmented into two groups, load funds and no-load funds. This division provides a sample of 180 load funds consisting of 21 aggressive growth (AG), 52 growth (G), 39 growth and income (GI), 22 balanced (B), and 46 bond and preferred stock (BP). The remainder of the sample consists of 143 no-load funds broken down into 22 (AG), 60 (G), 27 (GI), 14 (B), and 20 (BP). The monthly returns from each group are computed to provide an equally weighted 156-month index return from each group. Using equally weighted indexes is important since the objective is to determine the similarity of risk between the average load fund and the average no-load fund in a selected investment objective. Once the indices were computed, a modified market model, Equation (4), was used to determine the relative systematic risk.

$$
R_{L D I, t}-R_{f, t}=\alpha_{L D}+\beta_{L D}\left(R_{N L, t}-R_{f, t}\right)+\varepsilon_{t}
$$

where $R_{L D I, t}$ is the return on the load fund index for a given investment objective group during each month the 156month sample period, $R_{f, t}$ is the risk-free rate of interest (90 day US T-bills), $R_{N L I, t}$ is the return on the no-load fund index for a given investment objective group during each month $t$ of the 156-month sample period, and $\alpha_{L D}$ and $\beta_{L D}$ are the estimated excess risk-adjusted return and systematic risk coefficients of the load fund index. This permits determining whether the average risk of load funds differs systematically from that of no-load funds. If the risk of load and no-load funds is the same, the estimated $\beta_{L D}$ coefficient should not differ statistically from one.

Table 4 columns two through four provide the sample size for the total sample, the load fund sample, and the no-load fund sample respectively. Column five provides the systematic risk estimate generated by regressing the returns of the index of load funds on the index of no-load funds and column six is the adjusted coefficient of determination of the model. A beta of one would suggest equal risk whereas a beta with a confidence interval that excludes one would suggest that risk is significantly different between the two groups. Results suggest that systemic differences exist and the differences in risk are significant at the .05 level. These results are consistent with no-load portfolio managers holding more cash (e.g., Chordia (1996), Malhotra and McLeod (1997)) and having similar risky asset portfolio compositions. At a minimum, these findings suggest that

Table 4.

Homogeneity of Systematic Risk between Load and No-load Funds.

\begin{tabular}{cccccc}
\hline \multirow{2}{*}{$\begin{array}{c}\text { Investment } \\
\text { Objective }\end{array}$} & Total & Load & No-load & $\beta_{L D}$ & $\mathrm{R}^{2}$ \\
\cline { 2 - 6 } & 43 & 21 & 22 & $1.030^{*}$ & 0.986 \\
$\mathrm{AG}$ & 112 & 52 & 60 & $1.040^{*}$ & 0.991 \\
$(\mathrm{G})$ & 66 & 39 & 27 & $1.099^{*}$ & 0.989 \\
$(\mathrm{GI})$ & 36 & 22 & 14 & $1.066^{*}$ & 0.972 \\
$(\mathrm{~B})$ & 66 & 46 & 20 & $1.099^{*}$ & 0.951 \\
\hline
\end{tabular}

Note: This table presents the results of tests of whether systemic differences in risk exist between load and no-load funds. Column one is the CDA investment objective group. Columns two through four provide the sample size for the total sample, the load fund sample, and the no-load fund sample, respectively. Column five provides the slope estimate generated by regressing the returns of the index of load funds on the index of no-load funds over the 156-month sample period. A beta of one would suggest equal risk whereas a beta with a confidence interval that excludes one would suggest that risk is significantly different between the two groups. The model below estimates betas:

$$
R_{L D I, t}-R_{f, t}=\alpha_{L D}+\beta_{L D}\left(R_{N L, t}-R_{f, t}\right)+\varepsilon_{t}
$$

*Indicates that the .05 confidence interval does not include one. 
comparing funds within investment objective classes without considering the fee structure can be misleading.

\section{Load Adjusted Systematic Risk Homogeneity Tests}

To determine if systemic differences in risk between load and no-load funds were the sole cause of heterogeneous within group risk, the sample was partitioned into load and no-load sub samples and one-way ANOVA on betas was repeated for each sub sample. To conduct statistical testing, betas are computed using monthly data over rolling one-year periods for the thirteen-year period. This provides a distribution of betas for each fund. These betas are then compared using One-way ANOVA to test the equality of betas within each investment objective group for each load structure to learn if the average beta for all funds within the investment objective group is then equal.

Table 5 panels $\mathrm{A}$ and $\mathrm{B}$ present results of the one-way ANOVA F-test to determine if risk differences reported in Table 3 remain after controlling for load effects for load and no-load funds, respectively. Column one provides the CDA investment objective and column two is the number of funds comprising the sample. Columns three through five are the ANOVA F-statistic p-values for the null hypothesis that the risk for investors is homogeneous within the investment objective group. Results suggest that risk homogeneity is rejected for all five investment objective groups (for both the load and no-load subsamples) when the CRSP VW index is used. When using the CRSP EW index, risk homogeneity is rejected for two of the five investment objective groups in both the load and no-load subsamples. The MSCI index shows that for load funds, risk homogeneity is rejected for four of the five investment objective groups. No-load funds fare somewhat better but risk homogeneity is rejected for three of the five investment objec tive groups. Thus, while empirical results reveal that load funds exhibit statically higher risk, segmenting funds by load structure does not correct systematic risk heterogeneity within objective classifications.

\section{Examination of Total Risk}

Najand and Prather (1999) question whether investment objectives may do a good job of capturing elements of risk that are not captured by beta. Therefore, they examine the total variability of fund returns within each investment objective group. Since the number of degrees of freedom for each of the $r$ sample variances $\mathrm{s}_{i}{ }^{2}$ is equal, they use the Hartley test to determine whether differences in variance are significant. I also use the Hartley test to examine total risk over the 156-month period. Formally, Hartley is used to test:

HO: $\sigma_{1}{ }^{2}=\sigma_{2}{ }^{2}=\cdots=\sigma_{r}{ }^{2}$

HA: not all $\sigma_{i}^{2}$ are equal.

Equation (5) is used to compute the Hartley test statistic

$$
H=\max \left(s_{i}^{2}\right) / \min \left(s_{i}^{2}\right)
$$

where $\mathrm{H}$ is the Hartley statistic, $\max \mathrm{s}_{\mathrm{i}}{ }^{2}$ is the maximum sample variance and $\min \mathrm{s}_{i}{ }^{2}$ is the minimum sample variance. Critical $\mathrm{H}$ values are from David (1952).

Table 6 presents the results of the Hartley test on the total variance of funds within each of the CDA investment objective classes. Columns one and two provide the investment objective classification and the number of funds included in the sample, respectively. Column three provides the variance of the funds in the sample with the lowest variance and column four provides the variance of the funds in the sample with the highest variance. Column five provides the Hartley statistic, which is used to test whether the sample variances are significantly different. Results are presented for the load fund sample and the no-load fund sample in panels A and B, respectively. Hartley statistics suggests that the total risk is heterogeneous within each of the

Table 5.

CDA Systematic Risk Homogeneity after Controlling for Load.

Panel A. Load Fund Systematic Risk.

\begin{tabular}{ccccc}
\hline \multirow{2}{*}{$\begin{array}{c}\text { Investment } \\
\text { Objective }\end{array}$} & \multirow{2}{*}{ Number of Funds } & \multicolumn{3}{c}{ Index $(P$ value $)$} \\
\cline { 3 - 5 } & & CRSP EW & CRSP VW & MSCI \\
\hline AG & 21 & 0.9868 & 0.0004 & 0.1055 \\
(G) & 52 & 0.9943 & 0.0000 & 0.0000 \\
(GI) & 39 & 0.0389 & 0.0000 & 0.0000 \\
(B) & 22 & 0.2760 & 0.0000 & 0.0000 \\
(BP) & 46 & 0.0001 & 0.0000 & 0.0000 \\
\hline
\end{tabular}

Panel B. No-load Fund Systematic Risk.

\begin{tabular}{ccccc}
\hline \multirow{2}{*}{$\begin{array}{c}\text { Investment } \\
\text { Objective }\end{array}$} & \multirow{2}{*}{ Number of Funds } & \multicolumn{3}{c}{ Index $(P$ value $)$} \\
\cline { 3 - 5 } & & CRSP EW & CRSP VW & MSCI \\
\hline AG & 22 & 0.9438 & 0.0000 & 0.0003 \\
$(\mathrm{G})$ & 60 & 0.6063 & 0.0000 & 0.4859 \\
$(\mathrm{GI})$ & 27 & 0.0000 & 0.0000 & 0.0000 \\
$(\mathrm{~B})$ & 14 & 0.0161 & 0.0000 & 0.4535 \\
$(\mathrm{BP})$ & 20 & 0.0927 & 0.0016 & 0.0011 \\
\hline
\end{tabular}

Note: This table presents results of the one-way ANOVA F-test to determine if risk differences observed in Table 4 remain after controlling for load effects. Panel A presents the results for load funds and Panel B presents the results for no-load funds. Column one provides the CDA investment objective and column two is the number of funds comprising the sample. Columns three and four are the ANOVA F-statistic p-values for the tests of the null hypotheses that the risk for domestic only investors is homogeneous within the investment objective group. Column five is the ANOVA $P$-value for the test of the null hypothesis test that the risk for globally diversified investors (MSCI) is homogeneous within the investment objective group.

Table 6.

Homogeneity of CDA Total Risk.

Panel A. (Load Funds).

\begin{tabular}{ccccc}
\hline $\begin{array}{c}\text { Investment } \\
\text { Objective }\end{array}$ & $\begin{array}{c}\text { Number of } \\
\text { Funds }\end{array}$ & $\begin{array}{c}\text { Minimum } \\
\text { Variance }\end{array}$ & $\begin{array}{c}\text { Maximum } \\
\text { Variance }\end{array}$ & $\begin{array}{c}\text { Hartley } \\
\text { Statistic }\end{array}$ \\
\hline AG & 21 & 0.0017 & 0.0060 & $3.4509^{* * *}$ \\
(G) & 52 & 0.0013 & 0.0038 & $2.8406^{* *}$ \\
(GI) & 39 & 0.0006 & 0.0023 & $3.6887^{* * *}$ \\
(B) & 22 & 0.0005 & 0.0022 & $3.9873^{* * *}$ \\
(BP) & 46 & 0.0002 & 0.0013 & $7.9669^{* * *}$ \\
\hline
\end{tabular}

Panel B. (No-Load).

\begin{tabular}{ccccc}
\hline $\begin{array}{c}\text { Investment } \\
\text { Objective }\end{array}$ & $\begin{array}{c}\text { Number of } \\
\text { Funds }\end{array}$ & $\begin{array}{c}\text { Minimum } \\
\text { Variance }\end{array}$ & $\begin{array}{c}\text { Maximum } \\
\text { Variance }\end{array}$ & $\begin{array}{c}\text { Hartley Sta- } \\
\text { tistic }\end{array}$ \\
\hline AG & 22 & 0.0023 & 0.0049 & $2.0695^{* *}$ \\
(G) & 60 & 0.0009 & 0.0033 & $3.6717^{* * *}$ \\
(GI) & 27 & 0.0003 & 0.0024 & $8.4641^{* * *}$ \\
(B) & 14 & 0.0004 & 0.0013 & $3.2105^{* * *}$ \\
(BP) & 20 & 0.0000 & 0.0006 & $112.4264^{* * *}$ \\
\hline
\end{tabular}

Note: This table presents the results of the Hartley test on the total variance of funds within each of the eight CDA investment objectives. Columns one and two provide the investment objective classification and the number of funds included in the sample, respectively. Columns three and four provide the variances of the funds in the sample with the lowest and highest variance over the 156-month sample period, respectively. Column five provides the Hartley statistic, which is used to test whether the sample variances are significantly different. ${ }^{* * *},{ }^{* *}$ Indicates significance at the 0.01 and 0.05 levels, respectively. 
suggests that the total risk is heterogeneous within each of the CDA investment objective groups after controlling for risk differences between load and no-load funds. Because neither systematic nor total risk is homogeneous with investment objective classes, even after correcting for load effects, investment objectives are viewed as poor proxies for risk.

\section{Conclusion}

For investors to maximize utility, they must be able to build mutual fund portfolios that exhibit risk and return tradeoffs that the individual finds most appealing from the array of mutual funds available. After the investor determines their own risk tolerance they need two additional pieces of information to make utility maximizing choices - the return and risk of competing mutual funds. While historical returns are readily available, the risk of funds is much less clear.

If investors believe the early research in the field that investment objectives are valid risk proxies, they may compare raw returns of funds within an asset class and select the fund with the highest return. However, if earlier findings are not correct and if the risks of the funds within an investment objecttive classification differ, the capital asset pricing model and efficient market hypothesis would suggest that the investor may be unwittingly selecting the higher risk fund and ending up with lower utility.

I extend the findings of Najand and Prather (1999) to ascertain whether the load structure of the funds may drive their heterogeneous within class risk findings. If both load and no-load fund managers within a given investment objective class face similar constraints, the risk of the risky portfolio that they select should be similar. However, recent literature, (e.g., Chordia (1996), Goetzmann and Peles (1997), Ippolito (1992), Sirri and Tufano (1998)), suggests that agency problems may cause load and no-load fund managers to hold differing percentages of cash to meet uncertain redemptions. Therefore, it is possible that findings of risk heterogeneity are not due to lacking regulation or inability to properly capture risk. Rather, it may be a logical response by managers attempting to maximize their own utility.

To examine risk, I conduct empirical testing on monthly returns of more than 300 mutual funds over a thirteen-year period. Results suggest that the average risks of load and no-load funds differ statistically. After segmenting the sample into load and no-load funds, I examine the risk homogeneity of funds within investment objective classes using analysis of variance (ANOVA). Results suggest that risk is not homogeneous within investment objective classes and the risks of load and no-load funds generally differ. Moreover, the result is robust with respect to the selected market proxy.

\section{REFERENCES}

Brown, K. C., \& Brown, G. D. (1987). Does the composition of the market portfolio really matter? Journal of Portfolio Management, 13, 26-32. doi:10.3905/jpm.1987.26

Brown, K. C., Harlow, W. V., \& Starks, L. T. (1996). Of tournaments and temptations: An analysis of managerial incentives in the mutual fund industry. Journal of Finance, 51, 85-110. doi:10.1111/j.1540-6261.1996.tb05203.x

Chordia, T. (1996). The structure of mutual fund charges. Journal of Financial Economics, 41, 3-39. doi:10.1016/0304-405X(95)00856-A

David, H. (1952). Upper 5 and $1 \%$ points of the maximum F-ratio. Biometrika, 39, 422-424.

Goetzmann, W., \& Peles, N. (1997). Cognitive dissonance and mutual fund investors. Journal of Financial Research, 20, 145-158.

Grinblatt, M., \& Titman, S. (1989). Portfolio performance evaluation: Old issues and new insights. Review of Financial Studies, 2, 393-421. doi: $10.1093 / \mathrm{rfs} / 2.3 .393$

Grinblatt, M., \& Titman, S. (1992). The persistence of mutual fund performance. Journal of Finance, 47, 1977-1984. doi:10.1111/j.1540-6261.1992.tb04692.x

Grinblatt, M., \& Titman, S. (1993). Performance measurement without benchmarks: An examination of mutual fund returns. Journal of Business, 66, 47-68. doi:10.1086/296593

Grinblatt, M., \& Titman, S. (1994). A study of monthly mutual fund returns and performance evaluation techniques. Journal of Financial and Quantitative Analysis, 29, 419-444. doi:10.2307/2331338

Ippolito, R. (1992). Consumer reaction to measures of poor quality: Evidence from the mutual fund industry. Journal of Law and Economics, 35, 45-70. doi:10.1086/467244

Klemkosky, R. C. (1976). Additional evidence on the risk level discriminatory powers of the Weisenberger classifications. Journal of Business, 49, 48-50. doi:10.1086/295804

Lehmann, B., \& Modest, D. (1987). Mutual fund performance evaluation: A comparison of benchmarks and benchmark comparisons. Journal of Finance, 42, 233-265. doi:10.1111/j.1540-6261.1987.tb02566.x

Malhotra, D. K., \& McLeod, R. W. (1997). An empirical analysis of mutual fund expenses. Journal of Financial Research, 20, 175-190.

Najand, M., \& Prather, L. (1999). The risk level discriminatory power of mutual fund investment objectives: Additional evidence. Journal of Financial Markets, 2, 307-328. doi:10.1016/S1386-4181(99)00002-6

Sharpe, W. (1966). Mutual fund performance. Journal of Business, 39, 119-138. doi: $10.1086 / 294846$

Sirri, E., \& Tufano, P. (1998). Costly search and mutual fund flows. Journal of Finance, 53, 1589-1622. doi:10.1111/0022-1082.00066 